\section{A man with qualities}

John C. Marshall

Robert Musil and the Culture of Vienna.

By Hannah Hickman.

Croom Helm, London/Open Court

Publishing, La Salle, Illinois: 1984.

Pp. 203. f15.95, \$24.95.

THAT doctors (neurologists and psychiatrists in particular) should write fiction of compelling interest does not strike one as particularly surprising. Their working lives as secular priests allow them to poke around in corners of the body and soul that we usually try to keep well hidden from even our most intimate friends, and the "raw material" thus uncovered has supplied themes aplenty for such doctorwriters as Arthur Schnitzler, Ernst Weiss, Anton Chekhov, Géza Csáth and Alfred Döblin. Furthermore, the well-constructed case-report that young doctors are trained to present on ward-rounds ("On examination, ....") is itself a literary form of considerable power. Whatever one may think of them as "science", Sigmund Freud's early papers have the shape and elegance of superbly crafted short-stories. And Freud indeed once wrote to Schnitzler, a master of the short-story form, that he had always avoided him for fear of meeting his Doppelgänger.

That training as an experimental psychologist could yield a comparable input to the creative imagination sounds, at first blush, simply ridiculous. The discipline prides itself on providing "shallow" interpretations of "objective" behaviour elicited under carefully controlled conditions and subjected to rigorous methodological and statistical scrutiny. What could possibly be further from the lush profligacy of both fictional and "real" life? Yet it is exactly such a background, combined with the hard sciences and engineering, that provided the motive forces behind the only truly "modern" novel written in the twentieth century: Robert Musil's ironic dissection of the AustroHungarian Empire as it floated towards destruction in the First World War - The Man without Qualities. Many of us who misspent our youth reading Musil when we should have beeen studying for examinations will welcome Hannah Hickman's summary of Musil's life and work, and her analysis of the influences and experiences that made him the outstanding chronicler of the culture of Vienna in the Gay Apocalypse.

Robert Musil (1880-1942) spent his childhood and adolescence in Austrian military academies until in 1898, at odds with the intellectual and cultural values of army officers, he entered his father's department at the Technical University in Brno, Moravia, to train as a mechanical engineer. After a brief period as an assistant at the Technical University in Stuttgart, dissatisfaction with engineering as a philosophy of life provoked Musil to re-enroll as a student, this time at the University of Berlin. There he read logic, mathematics, physics and experimental psychology. Musil's professor was Carl Stumpf who had made important contributions to the study of auditory perception and to the psychology of music: Stumpf was also instrumental in unmasking "Clever Hans", the mathematical horse. Other students in the department in the early years of the century included Wolfgang Köhler, Max Wertheimer and Kurt Koffka, for whom Stumpf's stress on intrinsic perceptual organization was a crucial factor in their development of Gestalt psychology. Musil himself performed tachistoscopic experiments and devised a greatly improved colour wheel that became standard apparatus in all European laboratories of psychology. For his doctoral dissertation, however, Musil wrote an analysis of Ernst Mach's psychophysical theories. Mach's impressionistic materialism was not congenial to the department and "it was only after repeated arguments", Hickman recounts, "that Stumpf could be persuaded to accept Musil's thesis".

Both strands of Musil's psychological education emerged in his masterpiece. Ulrich - the man without qualities - lives through the first half of the novel as a fragmented empiricist, sardonically observing Franz Josef's reign as "Emperor of Peace"; but in the second half he attempts to recreate, in a potentially incestuous relationship with his sister, the vision of wholeness that informed the work of the Gestalt psychologists.

Although brief, Hannah Hickman's monograph gives a comprehensive account of Musil's writings, from his first novel (Young Törless) to his (unsuccessful) efforts to complete The Man without Qualities while in Swiss exile after the Anschluss. She draws extensively upon the published notebooks and letters and the many unpublished papers in the National Library of Austria; her wide reading is reflected in the particularly skilful way in which she interrelates Musil's biography, essays and fiction. Only a fraction of Musil's output has been translated into English (though his finest work, The Man without Qualities, is still in print). For the reader with little or no German, Hickman's study brilliantly fills out the background that will deepen one's appreciation of the major fiction.

The monograph will undoubtedly send the reader back to Musil with an increased awareness of the psyche of a writer who could employ such chapter titles as "From Koniatowski's critique of Danielli's theorem to the Fall of Man"; "So far as jurists are concerned, there are no semiinsane people"'; and, my own favourite, "A chapter that can be skipped by anyone who has no very high opinion of thinking as an occupation"'.

John C. Marshall is in the Neuropsychology Unit, part of the Neuroscience Group at the Radcliffe Infirmary, Oxford.

In business - jubilation in space, November 1982, as the Space Shuttle project starts to pay off with the successful launch of two commercial communications satellites from Columbia. The picture is reproduced from The Voyages of Columbia: The First True Spaceship by Richard S. Lewis, published (appropriately) by Columbia University Press. Price is $\$ 24.95, £ 20.80$. 